\title{
Pasireotide after Surgery for Persistent Cushing's Disease
}

Dan Nicolae PADURARU ${ }^{1,2}$, Carla SCANTEIE ${ }^{3}$, Alexandra BOLOCAN ${ }^{1,2}$, Octavian ANDRONIC ${ }^{1,2}$, Andra MORAR ${ }^{4}$, Cristina GHERVAN ${ }^{3,6}$, Raluca CIUNT ${ }^{3}$, Bogdan SOCEA ${ }^{2,7}$, Ovidiu BRATU ${ }^{1,8}$, Laura Maria DRAGOMIR ${ }^{3}$, Mara CARSOTE ${ }^{5}$, Ana VALEA ${ }^{3,6}$

\begin{abstract}
Introduction: Cushing's disease (CD) is characterized by multiple complications, particularly due to the condition itself, but also as a result of curative treatment. Nowadays, transsphenoidal surgery is considered the first-line therapy. Persistent hypercortisolism requires the initiation of medical therapy in order to limit the consequences of the disease. A common complication of pasireotide treatment is type 2 diabetes mellitus. We present a case of persistent Cushing's disease after transsphenoidal adenomectomy and pasireotide therapy, evaluated in several medical centers. Case presentation: A 27-year-old female was referred to our clinic for weight gain, hypertension, transient headache and recurrent depression. Clinical examination revealed plethoric moon face, purple striae, hirsutism with a Ferriman-Gallwey score of 14, acanthosis nigricans. The hormonal profile showed high ACTH (adrenocorticotropic hormone) levels (of $110.6 \mathrm{pg} / \mathrm{mL}$, normal: $7.2-63.3 \mathrm{pg} / \mathrm{mL}$ ), high urinary free cortisol (UFC) (of $846.5 \mu \mathrm{g} / 24 \mathrm{~h}$, normal: 50-190 $\mu \mathrm{g} / 24 \mathrm{~h}$ ) and serum cortisol, accompanied by non-suppression of cortisol after the $1 \mathrm{mg}$ DXM (Dexamethasone) suppression test (of $26.6 \mu \mathrm{g} / \mathrm{dL}$, normal: $18 \mu \mathrm{g} / \mathrm{dL}$ ) and adequate suppression after the overnight $8 \mathrm{mg}$ DXM test. Pituitary MRI (Magnetic Resonance Imaging) revealed a microadenoma measuring 4.3/4.4/6.2 mm. Transsphenoidal adenomectomy was recommended. After surgery, the patient developed multiple pituitary hormone deficiency, without significant remission of hypercortisolism. Pasireotide therapy was initiated, followed by inadequate control of hypercortisolism and the onset of type 2 diabetes mellitus, requiring oral antidiabetic agents and insulin. Conclusion: In persistent Cushing's disease, the challenge lies in identifying the optimal therapeutic methods in order to achieve a cure while, at the same time, limiting their side effects. Careful long-term follow-up by a multidisciplinary team is required.
\end{abstract}

Keywords: surgery, Cushing's disease, diabetes mellitus, pasireotide.

\section{Rezumat}

Introducere: Boala Cushing este caracterizată de complicații multiple, în mod particular din cauza bolii, dar şi ca rezultat al tratamentului curativ. În prezent, chirurgia transfenoidală este considerată tratamentul de primă linie.

\footnotetext{
${ }^{1} \mathrm{III}$ rd Department of General Surgery and Emergency, Emergency University Hospital, Bucharest, Romania

2 "Carol Davila" University of Medicine and Pharmacy, Bucharest, Romania

${ }^{3}$ Department of Endocrinology, County Clinical Emergency Hospital, Cluj-Napoca, Romania

${ }^{4}$ Clinical Hospital of Infectious Diseases, Cluj-Napoca, Romania

5 "C.I. Parhon" National Institute of Endocrinology, Bucharest, Romania

${ }^{6}$ "Iuliu Hatieganu" University of Medicine and Pharmacy \& County Clinical Hospital, Cluj-Napoca, Romania

${ }^{7}$ "Sf. Pantelimon" Clinical Emergency Hospital, Bucharest, Romania

8 "Dr. Carol Davila" Centtral Military Emergency University Hospital, Bucharest, Romania
}

\section{Corresponding author.}

Mara CARSOTE, "C.I. Parhon" National Institute of Endocrinology, Bucharest, Romania.

E-mail: carsote_m@hotmail.com 
Hipercortizolismul persistent necesită inițierea tratamentului medicamentos, pentru a limita consecințele bolii. 0 complicație comună a tratamentului cu pasireotide este diabetul zaharat de tip 2. Prezentăm un caz de boală Cushing persistentă după adenomectomia transsfenoidală şi terapia cu pasireotide, evaluat în câteva centre medicale. Prezentare de caz: 0 femeie de 27 de ani a fost trimisă către clinica noastră pentru câştig ponderal, hipertensiune, dureri de cap tranzitorii şi depresie recurentă. Examenul clinic a arătat facies în lună plină, pletoric, vergeturi, hirsutism cu un scor Ferriman-Gallwey de 14, acanthosis nigricans. Profilul hormonal a relevat niveluri crescute de ACTH (110,6 pg/mL, normal: 7,2-63,3 pg/mL), cortizol liber urinar (846,5 $\mu \mathrm{g} / 24 \mathrm{~h}$, normal: 50-190 $\mu \mathrm{g} / 24 \mathrm{~h})$ și cortizol seric, însoțite de lipsa de supresie a cortizolului după 1 mg dexametazonă (testul de supresie): 26,6 $\mu \mathrm{g} / \mathrm{dL}$, normal: $18 \mu \mathrm{g} /$ dL şi o supresie adecvată după testul nocturn cu 8 mg dexametazonă. RMN-ul hipofizei a arătat un microadenom măsurând 4,3/4,4/6,2 mm. Adenomectomia transsfenoidală a fost recomandată. După intervenția chirurgicală, pacienta a dezvoltat insuficiență hipofizară multiplă, fără o remisiune semnificativă a hipercortizolismului. A fost inițiat tratamentul cu pasireotide, urmat de un control inadecvat al hipercortizolismului şi instalarea diabetului zaharat de tip 2, necesitând tratament cu antidiabetice orale și insulină. Concluzie: În boala Cushing persistentă, dificultatea constă în identificarea metodelor terapeutice optime pentru a obține vindecarea, în acelaşi timp cu limitarea efectelor secundare. Urmărirea atentă de către o echipă multidisciplinară se impune.

Cuvinte cheie: chirurgie, boala Cushing, diabet zaharat, pasireotide.

\section{INTRODUCTION}

Although it is a rare disease, the increased morbidity associated with $\mathrm{CD}$ requires multiple therapeutic approaches, especially in case of persistent hypercortisolism. The first-line treatment is represented by transsphenoidal surgery, but medical therapy is a sustainable option in case of recurrent or persistent $\mathrm{CD}$, when surgery is contraindicated or until radiation therapy has taken full effect ${ }^{1}$. Pasireotide is a new-generation multi-receptor-targeted somatostatin receptor ligand used in the treatment of CD, but its effect on glucose metabolism should be taken into consideration when choosing the best treatment option for each patient ${ }^{2}$.

\section{CASE PRESENTATION}

A 27-year-old female was referred to our clinic for weight gain (50 kg in 8 years), occipital headache with frontal and retro-orbital radiation, fatigue, dyspnea, perspiration, mood swings corresponding to recurrent depressive episodes, worsening of hirsutism and the appearance of purple-red striae on the lower abdomen, thighs and under the breasts.

Her medical history revealed high blood pressure diagnosed 2 years prior and primary hypothyroidism.

Clinical examination revealed stage II obesity: weight of $100 \mathrm{~kg}$, height of $164 \mathrm{~cm}$, BMI (body mass index) of $36.73 \mathrm{~kg} / \mathrm{m}^{2}$, central distribution of adipose tissue, supraclavicular fat pads and buffalo hump, axillary and cervical acanthosis nigricans, hirsutism corresponding to a Ferriman-Gallwey score of 14, skin hyperpigmentation at the elbows and knees (Figure 1a, b), normal blood pressure (of 115/80 $\mathrm{mmHg}$ ) under triple-combination therapy: calcium blockers, angiotensin-converting enzyme inhibitor and diuretic.

The hormonal profile showed high levels of serum cortisol and UFC, broken cortisol circadian rhythm,

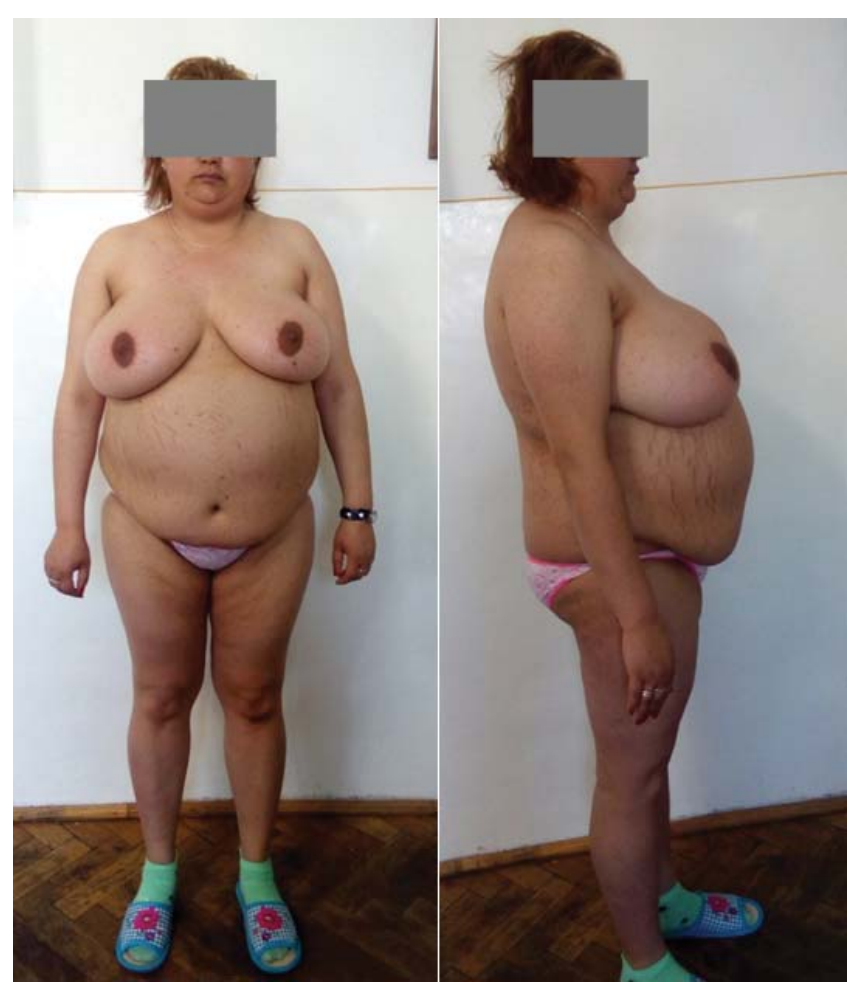

Figure 1A,B. Clinical presentation of a female patient diagnosed with Cushing' disease: central distribution of adipose tissue, supraclavicular fat pads, buffalo humpand purple-red striae on the lower abdomen. 
Table 1. Preoperative endocrine and biochemical parameters of a 27 year old female patient with Cushing disease

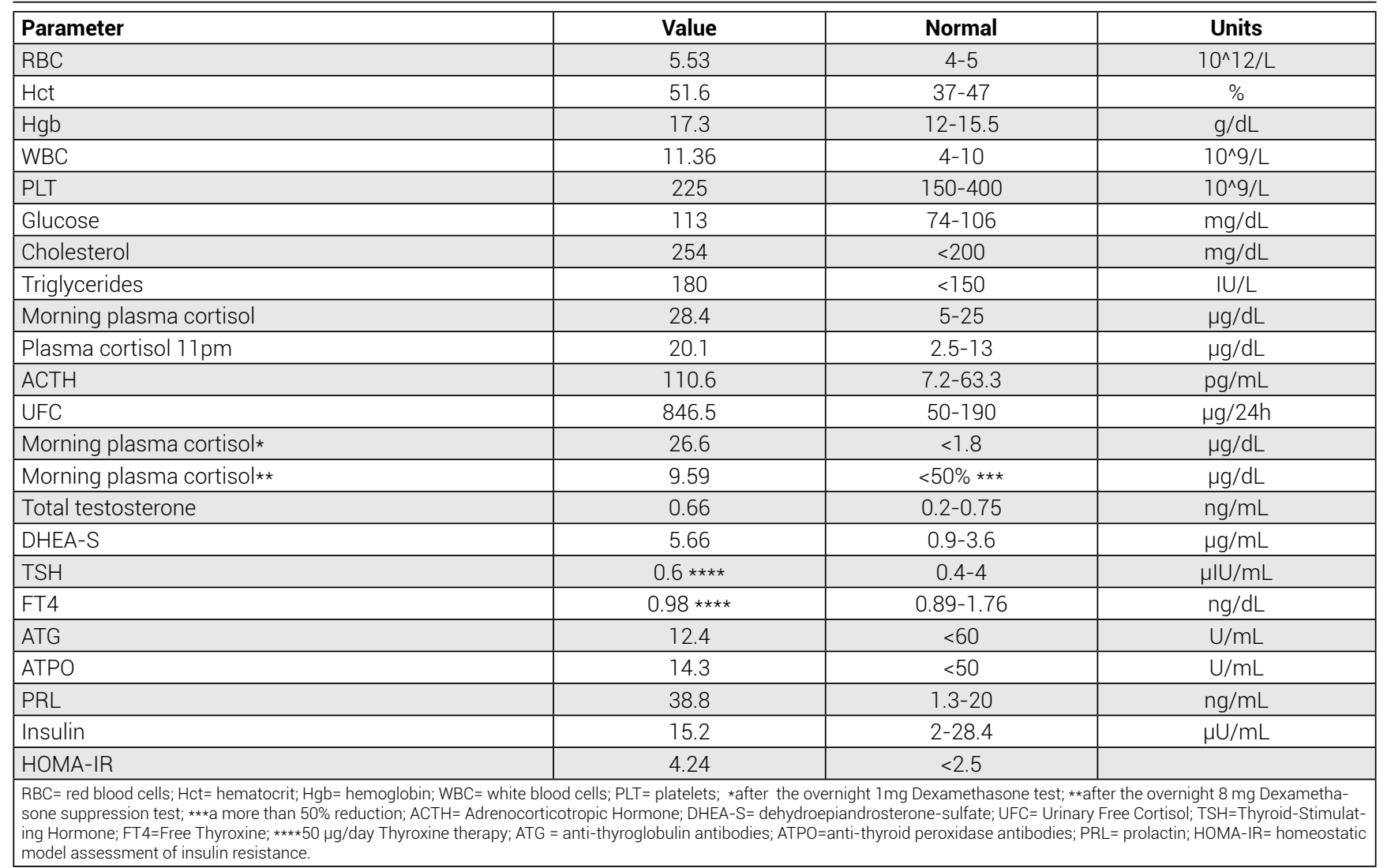

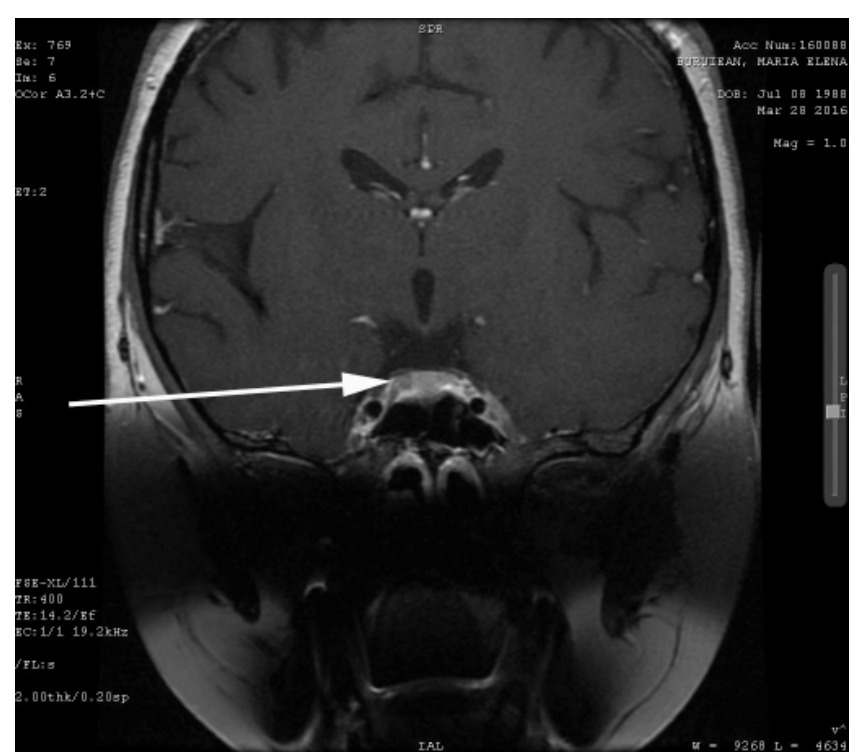

Figure 2. Preoperative contrast-enhancedpituitary MRI scan of a 27-year-old woman diagnosed with Cushing's disease: pituitary microadenoma measuring 4.3/4.4/6.2 mm. Coronal plane. high ACTH levels accompanied by non-suppression of morning cortisol after the $1 \mathrm{mg}$ DXM suppression test but with adequate suppression after the overnight $8 \mathrm{mg}$ DXM suppression test, normal testosterone levels with high DHEA-S (dehydroepiandrosteronesulfate), high prolactin levels, insulin resistance with a HOMA-IR (homeostatic model assessment of insulin resistance) score of 4.24 (normal<2.5), negative thyroid autoantibodies and normal thyroid function under thyroid replacement therapy (Table 1 ).

Biochemical workup revealed polycythemia, leukocytosis, fasting hyperglycemia, hypercholesterolemia and hypertriglyceridemia (Table 1). Pituitary MRI was performed, revealing a right pituitary microadenoma measuring 4.3/4.4/6.2 mm, with the pituitary stalk displaced to the left (Figure 2). Abdominal Computer tomography (CT) showed bilateral adrenal hyperplasia. The diagnosis of Cushing's disease was established and transsphenoidal adenomectomy was recommended. Because the patient initially refused surgery, treatment with pasireotide was initiated at a dose of $0.6 \mathrm{mg}$ twice daily. After 18 months she experienced spectacular weight loss of $32 \mathrm{~kg}$, her blood pressure normalized, requi- 
ring the cessation of antihypertensive therapy, but no significant reduction of ACTH and cortisol levels was reported. Moreover, the patient developed type 2 diabetes mellitus that was progressively treated with three antidiabetic drugs and insulin. After three months the patient underwent transsphenoidal adenomectomy, complicated with central diabetes insipidus which remitted 2 months later and multiple pituitary hormone insufficiency: thyroid stimulating hormone (TSH) deficiency (of $<0.004 \mu \mathrm{UI} / \mathrm{mL}$, normal: $0.4-4 \mu \mathrm{UI} / \mathrm{mL}$ ), gonadotropin insufficiency (FSH-follicular stimulating hormone of $3.76 \mathrm{U} / \mathrm{L}$, normal: $3.85-8.78 \mathrm{U} / \mathrm{L}, \mathrm{LH}-$ luteinizing hormone of $1.84 \mathrm{U} / \mathrm{L}$, normal: 2.12-10.9 $\mathrm{U} / \mathrm{L}$ ), somatotropin insufficiency (IGF1- insulin-like growth factor 1 of $91.9 \mathrm{ng} / \mathrm{mL}$, normal: 117-329ng/ $\mathrm{mL}$ ). Consequently, thyroxine dose was increased and combined oral contraceptive treatment was started. Because no significant remission of hypercortisolism was achieved, treatment with pasireotide $0.6 \mathrm{mg}$ twice daily was resumed three months later. Altered glycemic profile with high glycosylated hemoglobin of 7.6\% (normal:4.8-5.6\%) were reported after resumption of treatment, suggesting the recurrence of type 2 diabetes mellitus. In this case, a combination of the available drug therapies may be an alternative for optimal disease control, in order to limit the side effects.

\section{DISCUSSIONS}

Chronic elevation of cortisol levels leads to increased morbidity by altering the metabolic profile and body composition, inducing insulin resistance, muscle wasting, hypertension, fat maldistribution and neuropsychiatric disorders ${ }^{1,3}$. As a result, hypercortisolism must be treated effectively and, if possible, definitively.

Even though transsphenoidal pituitary adenomectomy provides adequate control of cortisol levels in 65$90 \%$ of patients with $\mathrm{CD}$, there are still patients who need medical therapy. In recent years, there has been increasing experience with first-line medical therapy, such as pasireotide ${ }^{2}$.

There are studies showing a normalization of UFC levels in $41.3 \%$ of 150 patients treated with various dosages of pasireotide over a 12-month period, establishing a direct link between the lowering of the UFC and the improvement of systolic and diastolic blood pressure and tumor volume reduction ${ }^{4,5}$.

Nevertheless, pasireotide has its adverse effects related to gastrointestinal symptoms and cholelitiasis, consistent with other somatostatin analogs (SSA), and a higher frequency of hyperglycemia ${ }^{2,6-8}$. In a metaanalysis, mild side effects were observed in $39.3 \%$ of patients and severe side effects were observed in 15.2\% of patients, respectively ${ }^{1}$.

Concerning the hyperglycemic effect associated with pasireotide treatment, $73 \%$ of patients in a 12 -month trial and $68.4 \%$ of patients in a 6 -month trial developed hyperglycemia as a side effect ${ }^{9-11}$. Our patient also developed hyperglycemia related to pasireotide, partially controlled by insulin and oral antidiabetic drugs. Moreover, treatment with Pasireotide was interrupted 18 months later due to partial control of hypercortisolism and the patient underwent transsphenoidal adenomectomy. After surgery, the glycemic parameters were restored to normal levels, but the persistence of glucocorticoid hypersecretion required further medical therapy. The same side effect, impaired glucose metabolism, reappeared and specific hypoglycemic therapy was resumed.

Regarding the mechanisms of Pasireotide-induced hyperglycemia, it has been reported that glucose metabolism is associated with the disease pathophysiology 2. Pasireotide binds both to SST2 (somatostatin receptor type 2) and SST5 (somatostatin receptor type 5), but with higher affinity to SST5. Insulin secretion is also mediated by SST2 and SST5 ${ }^{12}$. As a result, the hyperglycemic effects of Pasireotide in Cushing's disease are mainly due to its tendency to decrease incretin and insulin secretion ${ }^{13}$. Moreover, uncontrolled hypercortisolism in CD causes reduced insulin sensitivity which cannot be counterbalanced by reduced insulin levels associated with Pasireotide ${ }^{14}$.

Nonetheless, the hyperglycemic effect of Pasireotide is transient and can be explained by its absent effect on insulin sensitivity and minimal effects on glucagon secretion ${ }^{13}$.

In this case, a possible therapeutic approach would be the association of dopaminergic agonists, even if hyperprolactinemia has resolved postoperatively.

Regardless Cushing's disease or adrenal Cushing's syndrome, surgery remains the first line of approach ${ }^{15-18}$. However, opposite to adrenalectomy, surgical pituitary approach has a relatively low rate of success thus medical therapy is needed ${ }^{15-18}$.

\section{CONCLUSION}

In conclusion, in case of persistent Cushing's disease the challenge lies in identifying the optimal therapeutic methods in order to achieve a cure while, at the 
same time, limiting the side effects. Careful long-term follow-up by a multidisciplinary team is required for each patient.

Compliance with ethics requirements: The authors declare no conflict of interest regarding this article. The

\section{References}

1. Broersen LHA, Jha M, Biermasz NR, et al. Effectiveness of medical treatment for Cushing's syndrome: a systematic review and meta-analysis, Pituitary 2018; 21:631-41.

2. Silverstein JM. Hyperglycemia induced by pasireotide in patients with Cushing's disease or acromegaly, Pituitary 2016; 19:536-43.

3. Fernandez-Rodriguez E, Stewart PM, Cooper MS. The pituitaryadrenal axis and body composition, Pituitary 2009; 12(2):10515.

4. Lacroix A, Gu F. Gallardo W, et al. Efficacy and safety of oncemonthly pasireotide in Cushing's disease: a 12 month clinical trial, Lancet Diab Endocrinol 2018; 6(1):17-26.

5. Petersenn S, Salgado LR, Schopohl J, et al. Long-term (5 years) treatment of Cushing's disease with pasireotide. In: Poster presented at: European congress of endocrinology 2015, May 1620, Dublin, Ireland.

6. Signifor [package insert]. East Hanover, NJ: Novartis Pharmaceuticals Corporation (2012).

7. Valea A, Carsote M, Ghemigian A, Morar A, Pop DD, Georgescu CE. Severe hepatocytolisis syndrome - a challenge in medical therapy of Cushing's disease, Ars Medica Tomitana 2015; 3(21):132-136.

8. Furau R, Popa AR, Socea B, Dimitriu M, et al. Chemical liaison between diabetes and hypertension, depression and socio-economic deprivation impact in both, Rev. Chim. (Bucharest) 2019; 70(8):2977-2981 .

9. Colao A, Petersenn S, Newell-Price J, et al. Pasireotide B2305 study group: a 12-month phase 3 study of pasireotide in Cushing's disease, N Engl J Med 2012; 366(10):914-24.

10. Boscaro $M$, Bertherat J, Findling J, et al. Extended treatment of Cushing's disease with pasireotide: results from a 2-year, phase II study, Pituitary 2014; 17(4):320-6. authors declare that all the procedures and experiments of this study respect the ethical standards in the Helsinki Declaration of 1975, as revised in 2008(5), as well as the national law. Informed consent was obtained from all the patients included in the study.

11. Furau R, Popa AR, Furau C, lonescu C, et al. Correlations of the mechanisms involved in diabetes mellitus, peripheral arterial disease and gangrene leading to amputations - a retrospective study over the non-traumatic amputations performed in the Emergency Clinical County Hospital of Arad between 20142018, Rev. Chim. (Bucharest) 2019; 70(9):3309-3314;

12. Fagan SP, Azzizzadeh A, Moldovan S, et al. Insulin secretion is inhibited by subtype five somatostatin receptor in the mouse, Surgery 1998; 124(2):254-8 discussion 258-9.

13. Henry RR, Ciaraldi TP, Armstrong D, Burke P, Ligueros-Saylan M, Mudaliar S. Hyperglycemia associated with pasireotide: results from a mechanistic study in healthy volunteers, J Clin Endocrinol Metab 2013; 98(8):3446-53.

14. Kasayama S, Otsuki M, Takagi M, et al. Impaired beta-cell function in the presence of reduced insulin sensitivity determines glucose tolerance status in acromegalic patients, Clin Endocrinol (Oxf) 2000; 52(5):549-55.

15. Poiană C, Chiriță $C$, Carsote $M$, Hortopan $D$, loachim D, Corneci CM, Stănescu B. Adrenal and pituitary incidentalomas in a case of Cushing's syndrome, Chirurgia (Bucur) 2013; 108(6):886-91.

16. Paduraru DN, Nica A, Carsote M, Valea A. Adrenalectomy for Cushing's syndrome: do's and don'ts, J Med Life 2016; 9(4):334341.

17. Valea A, Ghervan C, Carsote M, Albu SE, Georgescu CE. Different surgical options in Cushing's disease, Journal of Surgical Sciences 2016; 3(1):39-43.

18. Carsote M, Ghemigian A, Valea A, Dumitrascu A, Chirita C, Poiana C. Subclinical Cushing's syndrome with bilateral adrenal tumours in a patient with gallbladder multiple stone: therapeutical options, Ars Medica Tomitana 2015; 21 (3):124-127. 
